\title{
Research on Ecological Compensation Mechanism of Typical Tourist Destination-A Case Study in Li River Basin
}

\author{
Dan-Dan Lu ${ }^{1, a}$, Yong-De Zhong, ${ }^{2, b,}$, Si-Yuan Chen ${ }^{3, c}$ \\ ${ }^{1}$ Central South University of Forestry and Technology, Changsha Hunan ,China; Guangxi University \\ of Finance and Economics, Nanning Guangxi ,China \\ ${ }^{2}$ Central South University of Forestry and Technology, Changsha Hunan, China \\ ${ }^{3}$ Guangxi University of Finance and Economics, Nanning Guangxi, China \\ aludandan163@163.com, byongde65@yahoo.com.cn, 'siyuanc@sina.com \\ ${ }^{*}$ Corresponding author
}

Keywords: Ecological compensation mechanism, Tourist destination, Li river basin.

\begin{abstract}
The ecological environment is the foundation of human existence and development, but the value of the ecological environment has not been fully recognized and fully reflect, this part of value has not got statistics and reasonable compensation for a long time. This paper analyzes the current situation of ecological compensation, the problems and the need for the establishment of ecological compensation mechanism in Li River Basin, to build the basic framework of ecological compensation in Li River Basin. The ecological compensation mechanism of Li River Basin should adhere to the government's dominant position, and at the same time give full play to the role of the market, and further improve the hematopoietic compensation system, promote the comprehensive, coordinated and sustainable development in Li River Basin.
\end{abstract}

\section{Introduction}

Ecological compensation mechanism is to solve the contradiction between the ecological environment and development, it is also an effective way to promote harmonious development between man and nature. In the traditional development mode, ecological value is often not taken into account, which leads to developers ascribe the damage caused by external diseconomies to society. The deterioration of ecological environment makes people paid more and more attention on the problem of ecological environment system service and value compensation. In recent years, ecological compensation as a new environmental management system, is a hot issue in the domestic and foreign multiple disciplines and fields.

Ecological compensation and social and economic development of $\mathrm{Li}$ River Basin are inextricably linked. Good ecological environment in Li River Basin is the background of socio-economic development, but because of historical, natural, economic and other reasons, the ecological function area are both poor mountainous area and ecologically fragile area. For a long time, people ignore the existence of the service value in Li River Basin ecosystem, the local residents lack compensation mechanics to the sacrifice for ecological protection and construction. It is guarantee for the eco-environment and socio-economic Li River watershed sustained, stable and healthy development to practice ecological compensation mechanism.

\section{Concept of Ecological Compensation}

Ecological compensation is actually a kind of institutional arrangement to solve the externality problem of ecological environment, is the application of Externalities-internalization-mechanism in ecological environment. International Ecological Compensation in general is "payments for ecosystem services" or "payments for ecological benefits ". There are mainly four types: (1) direct public compensation; (2) quota trade plan; (3) private direct compensation; (4) the ecological product certification program. Ecological compensation is the long-term overall protection and recovery to ecology and environment, and the adjustment to economic relationship among benefit subjects. It aims to arouse the enthusiasm of ecological construction and protector. It is a 
comprehensives of Interest driven mechanism, motivation mechanism, and coordination mechanism to promote the interests of the ecological protection.

\section{Research on Ecological Compensation Mode and Method}

Through the brief analysis and assessment to general research situation and research production from experts and scholars at home and abroad, there are diverse modes and methods of ecological compensation. There are two kinds of mainly mode. They are market leasing mode and government leading mode. Ecological compensation mechanism and practice create diverse ecological compensation form, induces mainly six kinds: funds compensation, policy compensation, material compensation, project compensation, technology compensation, intelligence compensation. Our country mainly adopts financial transfer payment and tax measures in the central and local, relevant laws and regulations and industry system is far from perfect and mature, even exist the phenomenon that lack of lack of policy and regulation.

\section{Present Situation of Ecological Compensation in Li River Basin}

\section{The Status of Ecological Compensation}

On 24th November, 2011, the Li River Basin ecological environment protection regulations passed in the 25th session of the Standing Committee of the 11th session of the Guangxi Zhuang Autonomous Region people's Congress, it has "milestone" meaning in the history of Li River protection. Guilin government has been committed to exploring the ecological compensation mechanism in Li River, and put forward the "six major projects" and "four modernizations" to better protect and develop the Li River. In the construction of ecological compensation mechanism, YangShuo county plays a exemplary role. County government allocated more than one hundred million yuan for poverty alleviation work, it is mainly used for raising, hydraulic engineering, water engineering of features along the river, improve the rural environment, optimization of power system, etc.; Spending two hundred million yuan used for tourism development projects; Using three million special funds for the new rural construction, optimize the industrial structure. Since the successful performance of Impression Liu Sanjie ", Take out more than ten million of the money used for the surrounding environmental protection, the income of local resident actors increased by 15000 yuan.

\section{Existing Problems}

(1)The overload use of ecological environment. Since the tourism developed in Li River Basin, in the recent thirty years, its ecological damage gradually appeared, and more and more intense. In the process of the development in Li River, Too much focus are paid on economic benefit, while ignoring the protection of ecological environment, it did different degrees of damage to the mountains, water, plants and animals and so on. (2) Too much proportion from government compensation, not give full play to the role of the market compensation. At present, the government's transfer payment, financial subsidies and control measures has been the primary means of ecological compensation, the role of market compensation has yet to be improved.(3)Low compensation standard, single compensation mode. Public forest protection, returning farmland to forest policy, such policies exist the following problems: low standard, short duration, lack of market base and so on. (4)Management system need to be further improved. Tourism industry is very comprehensive, whose boundary is fuzzy, therefore, to build the ecological compensation mechanism in tourism destination is more complicated than the general area.

\section{The Necessity of Ecological Compensation in Li River Basin}

(1) Ecological compensation mechanism is needed by the sustainable utilization of river basin Upstream is an important ecological function areas, it shows huge value for ecological environment, but cannot obtain economic benefits directly, therefore, it is particularly important to realize the ecological compensation of ecological environment conservation. (2) Ecological compensation mechanism is needed by the huge gap between environmentalists and beneficiaries. Most of river 
source region is often ecologically fragile, economic less-developed areas and poverty serious areas; While in the middle and lower reaches, the economy is relatively developed, it enjoys the ecosystem services brings from ecological protection of river basin. (3) Ecological compensation mechanism is needed by the development of tourism in Li River. Good environment is the guarantee of the tourism sustainable development. The development and protection of the Li River is related to the rise or fall of world famous scenic spot, it also related to the economic sustainable development of Li River Basin.

\section{Study on Ecological Compensation Mechanism in Li River Basin}

\section{Ecological Compensation Mode}

Ecological compensation mode in Li River Basin is in essence a direct payment between the resource benefits core stakeholders in Li River Basin ecological function areas, namely the main body of ecological protection (provider) and ecological interests winner (beneficiary). Ecological compensation mechanism in Li River Basin will help to change its compensation mode, the current compensation mode is "blood transfusion" mode, the newly established mode is mixed mode with hematopoietic compensation and blood-transfusion mode. The Li River Basin ecological compensation model is given priority to hematopoietic compensation mode, which not only ensure the effective development of compensation activities in time and space, but also strongly stimulate the supply and demand compensation, promoting the benign and maintain formation of the dynamic relationship between supply and demand compensation. Therefore, in the long run, Li River ecological compensation should rely mainly on hematopoietic compensation, while take blood-transfusion compensation as a secondary reliance.

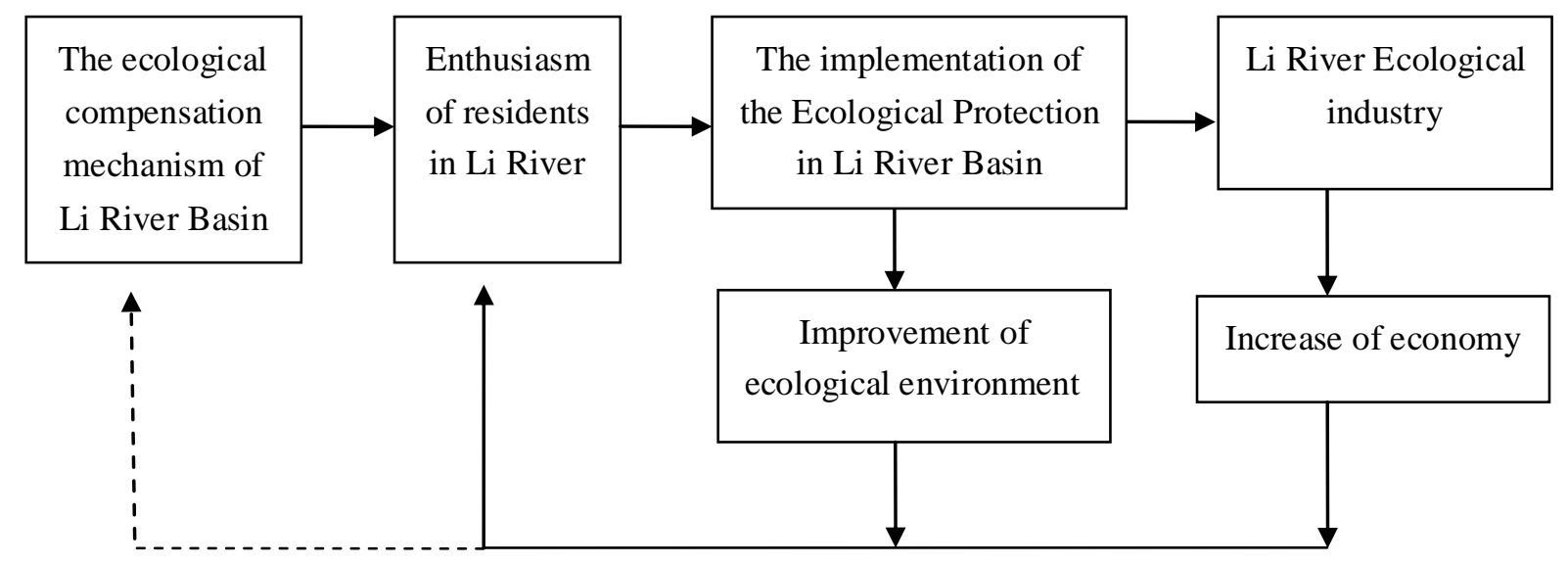

Fig.1 The effects of ecological compensation in Li River Basin

\section{Ecological Compensation Method}

For underdeveloped and ecological fragile regions in $\mathrm{Li}$ River Basin, under the mode of traditional blood-transfusion mode ecological compensation, its ecological environment protection and construction depth, breadth and intensity depends on the of external levels of blood transfusion, lack driving force and support force of ecological environment protection and construction, once stop blood transfusion, the ecological environment protection and construction activities in Li River will also cease. If can't solve the poverty of Li River Basin, it will face the risk of ecological degradation after the compensation stop. The table below is the ideas of the Li River Basin ecological compensation mode - hematopoietic supplemented, mixed with blood-transfusion mode, rely mainly on market, supplemented with government compensation mode. Blood- transfusion ecological compensation form including financial compensation, material compensation and policy compensation; Hematopoietic ecological compensation including project compensation, technology compensation and intelligence compensation. 
Tab.1 Ecological methods of compensation

\begin{tabular}{l|l|l}
\hline Compensation form & Compensation mode & $\begin{array}{l}\text { Compensation } \\
\text { method }\end{array}$ \\
\hline Blood transfusion mode & Government leading mode & $\begin{array}{l}\text { Fund compensation } \\
\text { Material } \\
\text { compensation } \\
\text { Policy compensation }\end{array}$ \\
\hline Hematopoietic compensation mode & Market leading mode & $\begin{array}{l}\text { Project } \\
\text { compensation } \\
\text { Technology } \\
\text { compensation } \\
\text { Intelligence } \\
\text { compensation }\end{array}$ \\
\hline $\begin{array}{l}\text { Mixed with hematopoietic } \\
\text { compensation and blood transfusion } \\
\text { compensation }\end{array}$ & by government mode & $\begin{array}{l}\text { Mixed compensation } \\
\text { mode }\end{array}$ \\
\hline
\end{tabular}

\section{The Source of Ecological Compensation}

It is needed to establish diversified, multi-level and multi-channel ecological compensation fund system by the government, the social, and beneficiary.

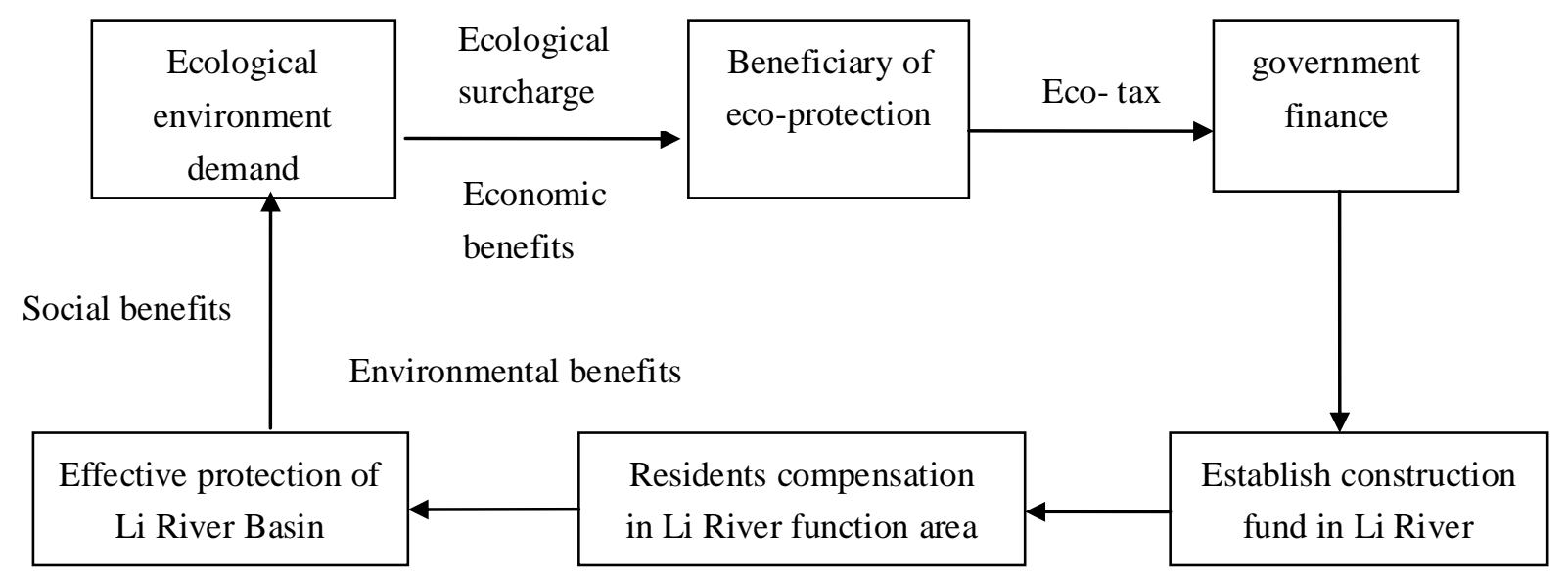

Fig.2 Hematopoietic eco-compensation mechanism in Li River Basin

Under the premise of clear compensation stakeholders, we can choose to collect compensation funds. The main source of ecological compensation is the ecological compensation funds that turned over by compensation subjects in Li River Basin, or the punishment of certain subject. In the process of the ecological compensation, we should concentrate on the principle "who damage who compensate, who benefit who compensate ". The enterprise, organizations and individual who make use of Li River's ecological resources to develop economy should be compensated, the proportion can according to government's legislation, or adjusted by market mechanism. Also those who make damages to the source and environment should be compensate.

Establish the ecological compensation fund of Li River Basin. The main source of funds is the national and provincial and municipal governments, which is the funds for the development and protection, and tax from the benefited enterprise, it is mainly used for the construction that pay a huge sacrifice for environmental protection. Sponsored content mainly includes the construction of infrastructure, environmental improvement and protection, project development, talent cultivation and so on. Special construction funds in Li River Basin will not put into use after a strict examination and approval, only those project that have obeyed the overall planning, and gotten 
approval will be funded. Li River Basin ecological environment protection can increase the carrying capacity of ecological environment, reducing ecological the throes of economic transformation, promote the development of society and economy, economic development can fully arouse the enthusiasm of the Li river basin, strengthen the consciousness of the protection of the water, both influence each other, promote each other.

\section{The Results Distribution of Ecological Benefits}

Li river basin ecological benefits cannot be assigned to individual, the compensation fund will not send to local residents, it is used to compensate for the public infrastructure and public service facilities in Li River Basin, such as traffic facilities, libraries, theaters, schools, health care, stadium, etc., compensation is allocated as a social public product and it is according to the coast of the $\mathrm{Li}$ River Basin region to pay the fund, makes the corresponding compensation. It is regarded as a public welfare compensation, compensates in public infrastructure and public service facilities, is managed by the public institutions of management committee, so that public compensation can benefit to all people. Ecological compensation funds should return to society, improve the social benefits, so that to achieve sustainable development the of Li River Basin.

\section{Construction of Ecological Compensation Policy System}

Ecological compensation legislation should be based on the legislation concept which is systematic, open and sustainable, setting a series of comprehensive legal system to regulate the development and utilization of river basin, and finally make the act of ecological compensation in river basin. The legal system include: legal system of river basin planning, system of river basin environmental impact assessment, water resources protection and distribution system, industrial development system, ecological compensation of river basin system and the ecological restoration and reconstruction, the legal liability system of river basin ecological compensation legislation.

\section{Conclusion}

Tourism in Li River is typical and representative in the tourism development of our country. In the long term, the ecological compensation mechanism in Li river basin should rely mainly on hematopoietic compensation while take blood-transfusion mode as a secondary reliance; The subject of Li River ecological compensation should be gradually transition from state compensation to the state-basin-society compensation together; Compensation mode should be gradually diversified, it should be transit from the fund compensation to industry compensation, technology compensation and talent compensation, give full play to the role of market compensation, improve the efficiency of compensation; At the same time, it is necessary to establish ecological compensation policy system, and protected by financial and tax propaganda policy. Ecological compensation in Li River is helpful to ease the contradiction between economic development and ecological protection, balance the rights and interests of stakeholders, and realize the sustainable development between the natural environment and tourism.

\section{Acknowledgement}

This research was financially supported by the National Science Foundation(71163004; 41461110).

\section{References}

[1]Junfeng Wang,Chaobo Hou. Study on Implementation Framework and Compensation Pattern of Basin Ecological Compensation Mechanism in China: From the Perspective of Compensation Funds Source ,J. China Population, Resources and Environment.23(2013)23-29.

[2]Ying Ma. A Comparative Study on the Incentive Compatibility of Modes of Basin Ecological Compensation ,J. Collected Essays on Finance and Economics.167(2012)27-33. 
[3]Guoying Li. Studies on ecological compensation mechanism of river basins,J. China Water Resources.12(2008)1-4.

[4] Junli Li, Kaicheng Gai. Study on the Inter-Regional Eco-compensation Mechanism of Three river source,J. Ecological Economy.235(2011)171-173.

[5]Tao Liu, Gang Wu,Xiao Fu.The watershed eco-compensation system from the perspective of economics: the cases of pollution compensation ,J. Acta Ecologica Sinica.32(2012)2985-2991.

[6]Wei Huang.Design Basis for Standard of Compensation \& Horizontal Compensation Mode in Watershed-Based PES,J. Ecological Environment.6(2013)154-159.

[7]Qing Wu, Jinwu Wang. Consideration on how to well-establish the basin ecological compensation system in China: case analysis of Dongjiang River Basin ,J. Ecology and Environmental Sciences.19(2010)751-756.

[8]Guihuan Liu,YihuiWen, Huiyuan Zhang.A Study on Ecological Compensation for the Guanting Reservoir Based on Ecosystem Services ,J. Resources Science.32(2010)856-863. 